\title{
Management and Organization Review Special Issue 'The Innovation and Entrepreneurship Ecosystem in India'
}

\author{
Call for Papers
}

\section{Guest Editors:}

\author{
Suresh Bhagavatula, ${ }^{1}$ Ram Mudambi, ${ }^{2}$ \\ and Johann Peter Murmann ${ }^{3}$ \\ ${ }^{1}$ Indian Institute of Management, Bangalore (sureshbh@iimb.ernet.in), ${ }^{2}$ Temple University \\ (ram.mudambi@temple.edu),and ${ }^{3} A G S M$-UNSW,Sydney (peter.murmann@unsw.edu.au)
}

Submission deadline: September 15, 2017

This Management of Organization Review (MOR) special issue aims to explore the key features of the innovation and entrepreneurship ecosystem in India. There is recent evidence that innovation and entrepreneurship dynamics in transforming economies differ from like processes in advanced market economies in significant ways (e.g., Maimone, Mudambi, Navarra, \& Baglieri, 2016). Therefore, applying the dominant theoretical lens developed to study innovation and entrepreneurship in advanced market economies may be inappropriate. For instance, the Global Entrepreneurship Monitor (GEM) surveys clearly demonstrate the composition of total entrepreneurial activity (TEA) for advanced and transforming economies is substantially different, with a significantly higher level of 'need-based' entrepreneurship in the latter. Hence the typical advanced economy transition from wage employment to a larger share for entrepreneurship may be reversed in transforming economies. Transforming economies also witness a significant role of the transnational diaspora in their entrepreneurial and innovation processes (Riddle, Hrivnak, \& Nielsen, 2010). Further, at the level of corporate entrepreneurship, London and Hart (2004) argue that results of studies of subsidiary entrepreneurship undertaken in advanced market economies may not generalize to transforming market economies. In summary, a fundamental question is whether entrepreneurship and innovation in transforming economies 
are diverging from the norms of advanced economies as these countries get wealthier and develop entirely new trajectories (Hill \& Mudambi, 2010).

After experiencing a modest 'Hindu rate of growth' for decades, post the 1991 liberalization, India transformed itself as one of the fastest growing countries in the world. In the process, it has developed from a closed and restricted to a progressively much more open and global oriented economy (e.g., Ghani, Kerr, \& O’Connell, 2014; Krishnan, 2010; Kumaraswamy, Mudambi, Saranga, \& Tripathy, 2012; Ramamurti, 1999). The liberalization involved the role of the government (Choudhury \& Khanna, 2010), industry development (Brandl \& Mudambi, 2013), corporate governance (Khanna \& Palepu, 2000), and connectivity (Lorenzen \& Mudambi, 2013).

Strangely, innovation and entrepreneurship have seldom been the focus of research examining the drivers of India's economic growth. This lacuna is surprising as innovation has been argued to be a key enabler of economic growth. Moreover, innovation and entrepreneurship in a large and increasingly globally connected country like India could provide insights on global as well as local networks in the global innovation system. More specifically, solving local problems can lead to innovation with spillovers that spread far beyond the country's borders, sparking effects in other transforming markets and even globally. Finally, entrepreneurship and entrepreneurial behaviour can transform the entire business environment of a country, as has been argued in the case of Israel (Chorev \& Anderson, 2006).

The objective of this Management and Organization Review (MOR) special issue is to explore the many dimensions of how the innovation and entrepreneurship ecosystem of India has impacted and been impacted by the accelerating development of the Indian economy over the last few decades. The special issue will take a pluralistic view of entrepreneurship and innovation. While studies based on patents are welcome, the editors are keen to see studies based on other innovation metrics. Similarly, while studies focused on high-tech sectors are invited, papers focused on low-tech sectors are encouraged. The guest editors are also soliciting exploratory empirical research that painstakingly describes phenomena that are not well explained by existing theories. In such cases, it would be premature to specify formal hypotheses and exploratory papers would focus on deep description of the phenomenon connected to innovation and entrepreneurship in India, articulating why existing theories are not adequate for explaining them, and offering some speculations on possible underlying causal processes.

All submitted empirical papers must satisfy MOR editorial policies of falsifiability, data transparency, and replication, and advance interesting implications for management theory, practice, and national policies.

The guest editors very much aspire that this special issue will make contributions to the academic literature on innovation and entrepreneurship on India, both in terms of the domestic economy but also in terms of its role in the global economy. The resulting insights will incorporate the roles of practitioners, and 
especially innovators and entrepreneurs, as well as policy makers from India as well as the wider world. Further, it will provide broader insights about the nature of entrepreneurship and innovation in the wider range of transforming markets.

\section{Suggested Research Questions}

The following list of potential research questions of interest to the special issue is neither exhaustive nor complete:

In the context of India:

1. How does the government impact innovation and entrepreneurship? For example, what policies or governmental activities influence innovation and entrepreneurship?

2. How does having a secure intellectual property environment or a lack of it impact innovation and entrepreneurship?

3. How has innovation and entrepreneurship impacted or helped the development India?

4. How does India's innovation and entrepreneurship impact compare to other transitioning economies (e.g., China)?

5. How do firm characteristics (e.g., business groups, SMEs, MNEs, Start-ups) impact innovation and entrepreneurship?

6. How does firm ecology impact innovation and entrepreneurship? For example, what attracts entrepreneurial firms to locate close to mature firms?

7. How does the local environment (e.g., cities, states) impact innovation and entrepreneurship?

8. How do industries (e.g., services, high tech, pharmaceutical, ICT) and their differences impact innovation and entrepreneurship?

9. What type and characteristics of innovation (e.g., frugal innovation, business model innovation, new product development) and entrepreneurship (e.g., including incubation) are most significant? and what are the drivers of these innovations?

10. What types of innovation are going to make the biggest contribution to lifting the standard of living for the average Indian citizen?

11. How do heritage and culture influence innovation and entrepreneurship?

12. What is the role of innovation and entrepreneurship in low technology industries?

\section{Deadlines, Submission, and Review Process}

Questions about the special issue may be directed to any of the guest editors. Papers for the special issue should be submitted electronically through MOR's ScholarOne 
Manuscripts site at http://mc.manuscriptcentral.com/mor and identified as submission to the 'Innovation and Entrepreneurship in India' special issue.

All submissions should follow the 'MOR Author Guidelines', available online at http://journals.cambridge.org/images/fileUpload/documents/MOR_ifc.pdf

After the first round of review, authors of manuscripts that receive an invitation to revise and resubmit will be invited to attend a Special MOR Paper Development Workshop which will be held at the Indian Institute of Management Bangalore.

\section{REFERENGES}

Chorev, S., \& Anderson, A. 2006. Success in Israeli high tech startups: Critical factors and process. Technovation, 26(2): 162-174.

Choudhury, P, \& Khanna, T. 2010. Privatization of innovation: evidence from India's state-owned laboratories. Working paper available at: http://papers.ssrn.com/sol3/papers.cfm?abstract_ id=1429001 (accessed 21 Jan 2017)

Ghani, E., Kerr, W. R., \& O'Connell, S. 2014. Spatial determinants of entrepreneurship in India. Regional Studies, 48(6): 1071-1089.

Hill, T. L., \& Mudambi, R. 2010. Far from Silicon Valley: How emerging economies are re-shaping our understanding of global entrepreneurship. Journal of International Management, 16(4): 321-327.

Khanna, T. \& Palepu, K. 2000. Is group affiliation profitable in emerging markets? An analysis of diversified Indian business groups. Journal of Finance, 55(2): 867-891.

Krishnan, R. T. 2010. From Jugaad to Systematic innovation: The challenge for India. Bangalore: Utpreraka Foundation.

Kumaraswamy, A., Mudambi, R., Saranga, H., \& Tripathy, A. 2012. Catch-up strategies in the Indian auto components industry: domestic firms' responses to market liberalization. Journal of International Business Studies, 43(4): 368-395.

London, T., \& Hart, S. 2004. Reinventing strategies for emerging markets: beyond the transnational model. Journal of International Business Studies, 35: 350-370.

Lorenzen, M., \& Mudambi, R. 2013. Clusters, connectivity and catch-up: Bollywood and Bangalore in the global economy. Journal of Economic Geography, 13(3): 501-534.

Maimone, D., Mudambi, R., Navarra, P., \& Baglieri, D. 2016. A tale of soil and seeds: the external environment and entrepreneurial entry. Small Business Economics, 47(4): 955-980.

Ramamurti, R. 1999. Why haven't developing countries privatized deeper and faster? World Development, 27(1): 137-155.

Riddle, L., Hrivnak, G., \& Nielsen, T. 2010. Transnational diaspora entrepreneurship in emerging markets: bridging institutional divides. Journal of International Management, 16(4): 398411. 